\title{
CALCULATION OF RADIO SIGNAL ATTENUATION USING LOCAL PRECIPITATION DATA*
}

\author{
S. Tamošiūnas ${ }^{a, b}$, M. Žilinskas ${ }^{b, c}$, A. Nekrošius ${ }^{b}$, and M. Tamošiūnienè ${ }^{d}$ \\ ${ }^{a}$ Institute of Materials Science and Applied Research, Vilnius University, Saulètekio 9, LT-10222 Vilnius, Lithuania \\ E-mail: stasys.tamosiunas@ff.vu.lt \\ ${ }^{\mathrm{b}}$ Vilnius University, Faculty of Physics, Sauletekio 9, LT-10222 Vilnius, Lithuania \\ ${ }^{\mathrm{c}}$ Communications Regulatory Authority of the Republic of Lithuania, Algirdo 27, LT-03219 Vilnius, Lithuania \\ ${ }^{\mathrm{d}}$ Semiconductor Physics Institute, A. Goštauto 11, LT-01108 Vilnius, Lithuania
}

Received 29 August 2005

\begin{abstract}
According to the peculiarities of climatic conditions of Lithuania the change in Chebil's model was made. For the first time the rain rate values for 13 localities in Lithuania have been calculated using this model. This data has shown that the definition of Rain Zone E does not describe the Lithuanian climatic conditions. The values of rain attenuation have been calculated as well. The Flavin's relationship for calculations of rain attenuation was used. The dependences of rain attenuation on the frequency for both locations of Ukmerge and Laukuva have been calculated. A review of the results on the rain rate and rain attenuation can be entered into total attenuation prediction or system-planning tools.
\end{abstract}

Keywords: rain attenuation, Flavin's relationship, Chebil's method

PACS: 41.20. Jb, 84.40.x.

\section{Introduction}

The electromagnetic waves are seriously affected by the atmosphere environments, in which the rainfall is the most important factor. At frequencies of $10 \mathrm{GHz}$ and higher heavy rain seriously attenuates radio transmissions because raindrops absorb and scatter radio waves [1]. Knowledge of the rain attenuation in this frequency range is desirable while planning a reliable communication system at any location. Rain attenuation is the major variable in the calculation of the total attenuation. Rain attenuation prediction similarly as weather prediction is not an exact science.

Several methodologies exist for the prediction of rain attenuation on radio waves paths [1]. These methodologies can be grouped into two classes: empirical methodologies based on measurement databases from stations in different climatic zones within a given region and physical models attempting to reproduce the physical behaviour involved in the attenuation process. The propagation characteristics in rain and melting snow are calculated in [2] by treating these media as artificial dielectrics. Computed values of attenuation

\footnotetext{
${ }^{*}$ The report presented at the 36th Lithuanian National Physics Conference, 16-18 June 2005, Vilnius, Lithuania.
}

and phase shift in rain, obtained by this approach, are compared with those derived by using Mie scattering theory over a frequency range of $1-100 \mathrm{GHz}$ and for rain rates up to $100 \mathrm{~mm} / \mathrm{h}$. Empirical procedures have tended to be used most often and with usually the best results. One of the most accepted methods for rain attenuation $A$ prediction is an empirical procedure based on the approximation relation between $A$ and the rain rate $R$ [3]:

$$
A=a R^{b},
$$

where $a$ and $b$ are functions of frequency $f$ and rain temperature $T$.

As shown in (1), attenuation due to rain depends on the rainfall intensity, or rain rate $R$. Rain rate data is presented in units of length per unit time (millimetres per hour), but in practice it is measured with a tipping bucket rain gauge over intervals of typically one minute [4] or five minutes [1]. The prediction of rain rate is the most important step when analysing rain attenuation. Rainfall rate is highly variable, both in terms of location and time (includes diurnal, seasonal, and yearly variations). Therefore the rain rate and rain attenuation are analysed for concrete climatic conditions, e. g., in Colombia [1], in Malaysia [4], in India [5], and in 
North America [6]. The rain attenuation and attenuation distribution have been obtained in [5] by using the measured rain drop size distribution and the ITU-R (International Telecommunication Union - Radio Regulations) model [7] of rain rate distribution, over the frequency range of $10-200 \mathrm{GHz}$ at three locations in the Indian region, to indicate the variability in the rain attenuation pattern in the tropical region. Considering that the raindrop size distribution and rain rate change with geographical location and this can strongly influence rain attenuation, [8] recommends the usage of an expanded set of power-law parameters for various raindrop distributions in calculating the specific attenuation. However, as far as we know, there are no data about the calculation of rain rates in Lithuania.

Lithuania, being in the transition geography zone from the Baltic Sea climate to Atlantic and continentals East Europe climate, may be distinguished for its variable climate. Continuous circulation of the air masses is one of the most important factors forming the Lithuania climate. Humid weathers predominate in Lithuania all over the year. It is often raining in spring, summer, autumn, and even in winter. There are 20-30 thaw days even in the very mid-winter. The relative humidity is $85-90 \%$ in spring and it is about $70 \%$ in summer. $60 \%$ of annual precipitation falls out in the warm period of the year [9]. The annual precipitation in rainy wet year is twice higher as compared to dry year. The distribution of precipitation is not uniform in Lithuania. The most humid location in Lithuania is Laukuva (in the Šilalè region), where the annual average precipitation is about $820 \mathrm{~mm}$ [9]. The named peculiarities of Lithuanian climatic conditions are valid reasons to use local Lithuanian meteorological data in rain attenuation calculation.

The main goals of this paper were to apply the known models to calculate the rain rate as well as the rain attenuation using local meteorological data of Lithuania.

\section{Calculation of rain rate and rain attenuation}

One method of predicting rain attenuation at a particular location is by using the relationship derived by Flavin [10] from analysis of measurements taken in Australia. This relation is given by the expression

$$
A=(0.0308 f-0.1872) R,
$$

where $A(\mathrm{~dB})$ is rain attenuation, $f(\mathrm{GHz})$ is the operating frequency, $R(\mathrm{~mm} / \mathrm{h})$ is the rain rate.
The effects of rain attenuation have been extensively studied over many years and the values of rain rates are available in ITU-R recommendations. The world has been divided into rain climatic zones marked from $\mathrm{A}$ to $\mathrm{Q}$ [11]. The rainfall rate is not uniform throughout the rainy area. In fact, the higher the rain rate the smaller area is affected. Therefore, when predicting the attenuation a path length reduction factor is introduced. This factor is dependent on $R$. As shown in [11], Lithuania is in Zone E, where the rain rate for $0.01 \%$ of time is $22 \mathrm{~mm} / \mathrm{h}$. However, for providing the objective additional information on rain rates for Lithuania we used local climatic data. The rain rate data are not always readily available from local weather agencies. Only the average annual precipitation is available in many cases. The use of Chebil's model appears suitable as an alternative for the sites where thunderstorm occurrence data are unavailable [1]. This model was verified against data from several localities resulting in the best estimate of measured data. It is exemplified by the following expression:

$$
R_{0.01 \%}=\alpha M^{\beta}
$$

where $\alpha=12.2903, \beta=0.2973, M$ is the average annual precipitation.

The averaged annual precipitation in several localities of Lithuania [12] and the values of rain rates calculated using (3) for 13 towns of Lithuania are presented in Table 1. The values of rain attenuation calculated using Flavin's relationship are presented in Table 1 as well. We obtained the difference of about $10 \%$ in the values of rain rates for different localities of Lithuania. The values of $R_{0.01 \%}$ calculated for Ukmergè and Laukuva using (3) differ from the value ascribed to Rain Zone E by $73 \%$ and $76 \%$, respectively. The values of $R_{0.01 \%}$ in different localities of Lithuania calculated using Chebil's model differ from the value ascribed to Rain Zone K by starting from $49 \%$ (in Ukmergè) up to 54\% (in Laukuva). So the calculated data of rain rate in Lithuania are closer to the value ascribed to Rain Zone $\mathrm{K}$ (which is near from Zone $\mathrm{E}$ ) than to the value ascribed to Rain Zone E.

The dependences of rain attenuation on the frequency for localities of both Ukmerge and Laukuva have been calculated in the frequency range from 10.5 to $40 \mathrm{GHz}$ (Fig. 1, straights 1 and 2) using (2). Rain attenuation increases at higher frequencies when wavelengths are close to the size of the raindrops.

Chebil's model was verified against data from several tropical localities with an average annual acummulation of 500-2000 $\mathrm{mm}$. The average annual precipita- 
Table 1. Average annual precipitation $M(\mathrm{~mm})$ in several localities of Lithuania (data is taken from [12]), values of rain rates $R_{0.01 \%}$, (mm/h) calculated using (3), values of rain rates $R_{0.01 \%}^{\prime}(\mathrm{mm} / \mathrm{h})$ calculated using (4), and rain attenuation calculated using relation (2).

\begin{tabular}{ccccccc}
\hline Locality & $M, \mathrm{~mm}$ & $0.6 \mathrm{M}, \mathrm{mm}$ & $R_{0.01 \%}, \mathrm{~mm} / \mathrm{h}$ & $R_{0.01 \%}^{\prime}, \mathrm{mm} / \mathrm{h}$ & $\begin{array}{c}A, \mathrm{~dB} \\
f=10.5 \mathrm{GHz}\end{array}$ & $\begin{array}{c}A, \mathrm{~dB} \\
f=26 \mathrm{GHz}\end{array}$ \\
\hline Biržai & 605 & 363 & 82.52 & 70.9 & 11.24 & 50.63 \\
Klaipėda & 735 & 441 & 87.44 & 75.12 & 11.91 & 53.65 \\
Laukuva & 821 & 492.6 & 90.36 & 77.63 & 12.31 & 55.44 \\
Kaunas & 630 & 378 & 83.52 & 71.76 & 11.38 & 51.25 \\
Kybartai & 613 & 367.8 & 82.85 & 71.17 & 11.28 & 50.84 \\
Šiauliai & 600 & 360 & 82.32 & 70.72 & 11.21 & 50.51 \\
Telšiai & 788 & 472.8 & 89.27 & 76.69 & 12.16 & 54.78 \\
Raseiniai & 682 & 409.2 & 85.52 & 73.47 & 11.65 & 52.48 \\
Šilutė & 737 & 478.2 & 89.57 & 76.95 & 12.2 & 54.96 \\
Utena & 650 & 390 & 84.3 & 72.42 & 11.48 & 51.73 \\
Varėna & 658 & 394.8 & 84.61 & 72.69 & 11.52 & 51.92 \\
Ukmergė & 588 & 352.8 & 81.83 & 70.3 & 11.15 & 50.21 \\
Vilnius & 683 & 409.8 & 85.55 & 73.5 & 11.65 & 52.49 \\
\hline
\end{tabular}

tion varied from 588 to $821 \mathrm{~mm}$ in several investigated localities of Lithuania (see Table 1) and these values were from the named range. It is important to note that a part of the annual precipitation in Lithuania is snowfall. Only $60 \%$ of the annual precipitation falls in the warm period of the year [9]. It is noted in [13] that the values of snow attenuation are much lower than the rain attenuation values and therefore it is recommended to neglect this type of attenuation in super high frequency (SHF) range. According to this peculiarity of Lithuanian climatic conditions we made a change in (3). For such mixed meteorological conditions, if there is no annual rain data and only annual precipitation data is available, this equation can be written as

$$
R_{0.01 \%}^{\prime}=\alpha(\gamma M)^{\beta},
$$

where $\gamma \leq 1.0$ is a coefficient of warm period in a year.

Then the relation (2) can be written as

$$
A^{\prime}=(0.0308 f-0.1872) \alpha(\gamma M)^{\beta} .
$$

The values of rain rates $R^{\prime}$ for investigated localities of Lithuania calculated using (4) are given in Table 1. Even in this "improved" case the obtained values of rain rates vary from $70.3 \mathrm{~mm} / \mathrm{h}$ (in Ukmergè) to $77.6 \mathrm{~mm} / \mathrm{h}$ (in Laukuva) and are higher than the values ascribed to Rain Zone E according to ITU Radio Regulations [11]. It is worth to emphasize that in ITU Radio Regulations of 1990 five different Rain Zones have been used [14]. According to that data Lithuania was ascribed to Rain Zone 2 with rain rate of $55 \mathrm{~mm} / \mathrm{h}$ that is much closer to local meteorological values presented in this paper. These values are from 3.7\% to about $13 \%$ higher than the value $R_{0.03 \%}=67.7 \mathrm{~mm} / \mathrm{h}$ calculated using the data on the longest heavy rain measured in
Table 2. Values of rain attenuation calculated using relation (5).

\begin{tabular}{cccc}
\hline Locality & $\begin{array}{c}A^{\prime}, \mathrm{dB} \\
f=10.5 \mathrm{GHz}\end{array}$ & $\begin{array}{c}A^{\prime}, \mathrm{dB} \\
f=26 \mathrm{GHz}\end{array}$ & $\begin{array}{c}A^{\prime}, \mathrm{dB} \\
f=40 \mathrm{GHz}\end{array}$ \\
\hline Biržai & 9.66 & 43.5 & 74.07 \\
Klaipėda & 10.23 & 46.09 & 78.48 \\
Laukuva & 10.57 & 47.64 & 81.11 \\
Kaunas & 9.77 & 44.03 & 74.97 \\
Kybartai & 9.69 & 43.67 & 74.36 \\
Šiauliai & 9.63 & 43.39 & 73.89 \\
Telšiai & 10.44 & 47.06 & 80.13 \\
Raseiniai & 10.01 & 45.08 & 76.76 \\
Šilutė & 10.48 & 47.22 & 80.4 \\
Utena & 9.86 & 44.44 & 75.67 \\
Varėna & 9.9 & 44.6 & 75.94 \\
Ukmergė & 9.58 & 43.14 & 73.45 \\
Vilnius & 10.01 & 45.1 & 76.79 \\
\hline
\end{tabular}

Sartai [15]. The value $R_{0.03 \%}=67.7 \mathrm{~mm} / \mathrm{h}$ is only $4 \%$ higher than the value ascribed to Rain Zone $\mathrm{N}$ and it is $82.3 \%$ higher than the one ascribed to Rain Zone $\mathrm{E}$ for $0.03 \%$ of time.

It is worth to mention that the review of Lithuanian climatic conditions and the obtained data about the rain rates in towns investigated here show that the definition of Rain Zone E does not describe the Lithuanian climatic conditions correctly.

The values of rain attenuation calculated by using relation (5) for 13 towns of Lithuania are presented in Table 2. The conditions of the radio signal propagation due to rain in Laukuva are worse than in other here investigated localities of Lithuania. The dependences of rain attenuation on the frequency for Laukuva (straight 3 ) and Ukmerge (straight 4) calculated using relation (5) are presented in Fig. 1. The rain attenuation values 


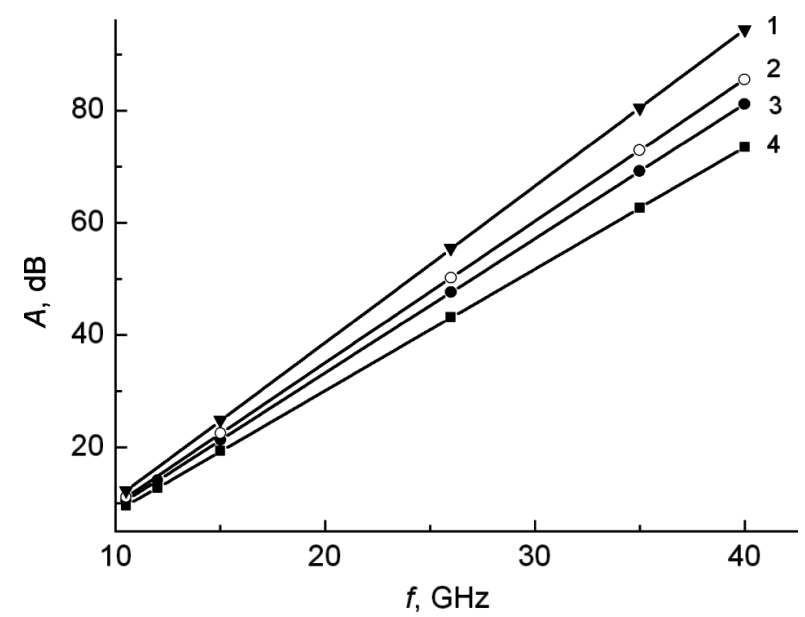

Fig. 1. Dependences of rain attenuation on the frequency for Laukuva (straights 1 and 3) and Ukmerge (straights 2 and 4). Straights 1 and 2 were obtained using relation (2). Straights 3 and 4 were calculated using relation (5).

decrease 1.16 times when the change in the relation (5) is made.

\section{Conclusions}

The conditions of the radio signal propagation due to rain in Laukuva are worse than in other here investigated localities of Lithuania. Considering that the rain rate is changing with geographical location and that it can strongly influence the rain attenuation, we recommend the usage of local meteorological data.

The definition of Rain Zone E does not describe correctly enough the Lithuanian climatic conditions and there is a need to specify this Rain Zone ascription.

The maximum difference of the values of rain attenuation in the investigated localities is about $8 \mathrm{~dB}$ when the signal frequency $f=40 \mathrm{GHz}$.

Investigation of meteorological data shows the necessity to modify Chebil's model.

\section{References}

[1] L.D. Emiliani, J. Agudelo, E. Gutierrez, J. Restrepo, and C. Fradique-Mendez, Development of rainattenuation and rain-rate maps for satellite system design in the $\mathrm{Ku}$ and $\mathrm{Ka}$ bands in Colombia, IEEE Antennas Propag. Mag. 46(6), 54-68 (2004).
[2] M.M. Kharadly and A.S.V. Choi, A simplified approach to the evaluation of EMW propagation characteristics in rain and melting snow, IEEE Trans. Antennas Propag. 36(2), 282-296 (1988).

[3] R.L. Freeman, Radio System Design for Telecommunications (John Wiley \& Sons, Inc., New York, Chichester, Weinheim, Brisbane, Singapore, Toronto, 1997).

[4] J. Chebil and T.A. Raihman, Development of the oneminute rain rate contour maps for microwave applications in Malaysia peninsula, Electron. Lett. 35(20), 1772-1774 (1999).

[5] A. Maitra, Rain attenuation modeling from measurements of rain drop size distribution in the Indian region, IEEE Antennas Wireless Propag. Lett. 3, 180181 (2004).

[6] R.K. Crane and D.V. Rogers, Review of the Advanced Communications Technology Satellite (ACTS) propagation campaign in North America, IEEE Antennas Propag. Mag. 40(6), 23-27 (1998).

[7] Specific Attenuation Model for Rain for Use in Prediction Methods, International Telecommunications Union Recommendation ITU-R P.838 (1992).

[8] W. Zhang and N. Moayeri, Recommendation: Use of various raindrop size distributions for different geographical locations in calculating the rain specific attenuation, Project IEEE 802.16 Broadband Wireless Access Working Group (1999).

[9] A. Bagdonas and R. Karalevičienè, The Reference Book of Agrometeorologist (Vilnius, Mokslas, 1987) [in Lithuanian].

[10] K. Barkeshli, Rain attenuation, http://sina.sharif.ac.ir/ barkeshli/ antennas/review/9510_032.htm

[11] Method for the determination of the coordination area around an earth station in frequency bands between $100 \mathrm{MHz}$ and $105 \mathrm{GHz}$, in: The ITU Radio Regulations, Appendices 7 to the Radio Regulations 2, 111206 (Geneva, 2004).

[12] Weather Forecasts, http://www.dmi.dk/dmi/index/

[13] A. Ishimaru, Wave Propagation and Scattering in Random Media (Academic Press, New York, San Francisco, London, 1978).

[14] Method for determination of the coordination area around an earth station in frequency bands between $1 \mathrm{GHz}$ and $40 \mathrm{GHz}$ shared between space and terrestrial radiocommunication services, in: The ITU Regulations, Appendices 28 to the Radio Regulations 2, AP28-1 - AP28-51 (Geneva, 1990).

[15] V. Navaitis, The Book of the Records in Lithuania (Vilnius, Žara, 2003) [in Lithuanian]. 


\title{
RADIJO SIGNALO SILPNINIMO SKAIČIAVIMAS, NAUDOJANT VIETINIUS DUOMENIS APIE KRITULIUS
}

\author{
S. Tamošiūnas ${ }^{a, b}$, M. Žilinskas ${ }^{b, c}$, A. Nekrošius ${ }^{b}$, M. Tamošiūniené ${ }^{d}$

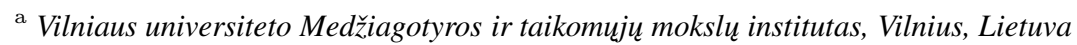 \\ ${ }^{\mathrm{b}}$ Vilniaus universitetas, Vilnius, Lietuva \\ ${ }^{\mathrm{c}}$ Lietuvos Respublikos Ryšiu reguliavimo tarnyba, Vilnius, Lietuva \\ ${ }^{\mathrm{d}}$ Puslaidininkiu fizikos institutas, Vilnius, Lietuva
}

\begin{abstract}
Santrauka
Projektuojant radijo stotis Lietuvoje, tenka atsižvelgti i radijo signalo silpninimą lietuje, o norint ji apskaičiuoti, reikia žinoti lietaus intensyvuma, tačiau dažnai žinomas tik vidutinis metinis kritulių kiekis. Taikant Chebil'io modelį, kuris naudojamas kaip alternatyva, kai nèra tikslių duomenų apie lietingas dienas, pirmąkart apskaičiuotas lietaus intensyvumas $0,01 \%$ metu laiko $R_{0,01 \%}$ $(\mathrm{mm} / \mathrm{h})$ trylikoje Lietuvos miestų. Pasinaudojus šiomis vertemis, pagal Flavin'o sąryši apskaičiuotas signalo silpninimas dèl lietaus Biržuose, Klaipėdoje, Laukuvoje, Kaune, Kybartuose, Šiauliuose, Telšiuose, Raseiniuose, Šilutėje, Utenoje, Varẻnoje, Ukmergèje ir Vilniuje. Priklausomai nuo ištirtos vietovès geografinès pa-
\end{abstract}

dèties, silpninimas lietuje gali skirtis iki $3 \mathrm{~dB}$, kai signalo dažnis $f=10,5 \mathrm{GHz}$, o kai $f=40 \mathrm{GHz}$, silpninimas lietuje skiriasi net $8 \mathrm{~dB}$.

Skaičiuojant lietaus intensyvumą Lietuvos sąlygomis, Chebil'io modelyje rekomenduota ịvesti koeficientą, kurio skaitinè verte parenkama atsižvelgus i tai, kurią metinio kritulių kiekio dali sudaro lietaus krituliai.

Lietuvos klimato ypatumu analizè bei šiame darbe apskaičiuotu lietaus intensyvumo verčiu palyginimas su Tarptautinès radijo ryšiu sajungos rekomenduota verte rodo, kad E lietaus zonos, kuriai priskiriama Lietuvos teritorija, apibrèžimas netiksliai apibūdina Lietuvos klimato sąlygas. 